\title{
Boehmeria glomerulifera Miq. Exhibits in vivo Antidepressant and Antidiarrheal Activities
}

\author{
Muhammed Mahfuzur Rahman ${ }^{1}$, Sharmin Khandker Shampa ${ }^{1}$, \\ Md. Abdul Bari ${ }^{1}$, Mohammad Kaisarul Islam ${ }^{2}$ and Mohammad A. Rashid ${ }^{2}$ \\ ${ }^{1}$ Department of Pharmacy, State University of Bangladesh, Dhaka-1205, Bangladesh \\ ${ }^{2}$ Phytochemical Research Laboratory, Department of Pharmaceutical Chemistry \\ University of Dhaka, Dhaka-1000, Bangladesh
}

(Received: February 12, 2019; Accepted: April 4, 2019; Published: July 22, 2019)

\begin{abstract}
Boehmeria glomerulifera Miq., is medicinal herb belongs to the family Urticaceae. It is used for treating various diseases by folk practitioners and rural people. The CNS antidepressant and antidiarrhoeal activities of the crude extract were investigated at 200 and $400 \mathrm{mg} / \mathrm{kg} \mathrm{bw}$ in Swiss Albino mice model. The crude methanolic extract revealed significant $(\mathrm{p}<0.05)$ antidepressant activity in mice at $400 \mathrm{mg} / \mathrm{kg}$ bw. On the other hand, in the castor oil-induced antidiarrheal assay, the extract demonstrated significant $(\mathrm{p}<0.05)$ antidiarrhoeal activity at $400 \mathrm{mg} / \mathrm{kg}$ bw.
\end{abstract}

Key words: Boehmeria glomerulifera, cytotoxic, sedative, anti-diarrheal.

\section{Introduction}

Plants have been used by the people as remedies for diversified diseased conditions since ancient time. At the beginnings, the uses of medicinal plants were instinctive, as is the case with animals (Stojanoski et al., 1999). Plants remain to be the source of treatment and prophylaxis before the advent of iatrochemistry in 16th century (Kelly et al., 2009). Nonetheless, the decreasing efficacy of synthetic drugs and the increasing contraindications have made the usage of plant-based medicines significantly (Petrovska et al., 2012).

In the developing world, estimated four billion people (representing $80 \%$ of the world's population) rely on herbal medicinal products as primary source of healthcare and traditional medical practice. These involves the use of herbs which is viewed as an integral part of the culture in those communities (Mukherjee et al., 2002; Bodeker et al., 2005; Bandaranayake et al., 2006).
According to the estimation of World Health Organization (WHO), the present global herbal market is of about US\$ 83 billion per year (Inamdar et al., 2008). The sale of herbal medicines is expected to get higher with about at $6.4 \%$ average annual growth rate. Due to the contribution of numerous significant factors, the market of herbal medicines has grown at an expressive rate worldwide (Borris et al., 1996).

Boehmeria glomerulifera, commonly known as false nettle, is a flowering plant belonging to the Urticaceae family. It is a deciduous shrub or small trees with spreading branches (Jiarui et al., 2003). The plant is widely distributed in Bangladesh, Bhutan, India, Indonesia, Laos, Myanmar, Sikkim, Sri Lanka, Thailand, and Vietnam. Traditional healers use the fresh leaves of this plant to treat anaemia in combination with Amomum aromaticum Roxb (Rahman et al., 2007). The bath with boiled

Correspondence to: Mohammad A. Rashid; Phone: +8801711947741; Email: r.pchem@du.ac.bd

DOI: https://doi.org/10.3329/bpj.v22i2.42302 
leaf-water is prescribed in case of fever of babies. It is also used as ornamental plants.

The biological activities of $B$. glomerulifera have not been explored extensively. As a part of our ongoing research program (Khan et al., 2014; Faruk et al., 2015; Khan et al., 2015) the present study has been undertaken and we, herein, report the antidepressant and anti-diarrheal activities of the leaf extract of B. glomerulifera for the first time.

\section{Materials and Methods}

Collection of plant materials and extraction: The leaves of $B$. glomerulifera were collected in December, 2014 identified by the taxonomist of Bangladesh National Herbarium, Dhaka, where a voucher specimen (DACB Accession no: 39726) has been maintained.

After proper washing, the leaves were sun dried for several days and then oven dried for 24 hours at considerably low temperature (not more than $40^{\circ} \mathrm{C}$ ) to facilitate better grinding. The dried plant material was then ground to a coarse powder using high capacity grinding machine. The powdered material $(350 \mathrm{~g})$ was taken in a clean, amber color reagent bottle (5 liters) and soaked in $2 \mathrm{~L}$ of methanol for 15 days accompanying occasional shaking and stirring. The whole mixture was then filtered through a fresh cotton plug and finally Whatman No. 1 filter paper. The filtrate was dried using a vacuum rotary evaporator at $40^{\circ} \mathrm{C}$ to obtain the gummy crude extract of B. glomerulifera.

Drugs and chemicals: Tween-80 (BDH Chemicals Ltd.) was used for getting uniform dispersion of the extract in normal saline. Sterile normal saline solution $(0.9 \% \mathrm{NaCl})$ from Beximco Infusion Ltd. (Bangladesh) was used as vehicle for standard and test samples. Chlorpromazine and loperamide were used as standard and phenobarbitone sodium and castor oil were utilized for inducing sleep and diarrhea, respectively.

Animal: Swiss-albino mice of either sex, aged 45 weeks were used for the experiment. They were housed in standard polypropylene cages and kept under controlled room temperature $\left(25 \pm 2.0^{\circ} \mathrm{C}\right.$; relative humidity $55-60 \%$ and $12 \mathrm{hrs} \mathrm{light-dark} \mathrm{cycle)}$ and fed with icddr,b formulated rodent food and water (ad-libitum). As these animals are very sensitive to environmental changes, before the test, they are kept in the laboratory environment for at least 3-4 days where the experiment will take place. The ethics for use of experimental animals were followed carefully.

Antidepressant activity: Antidepressant activity was evaluated by using phenobarbitone induced sleeping time test according to the established method (Turner et al., 1972). The animals were divided into four groups containing three mice in each group. The control group was administered normal saline water containing $1 \%$ Tween-80 solution, while the test groups were administered with test samples (standard chlorpromazine and plant extract at 200 and $400 \mathrm{mg} / \mathrm{kg}$ bw of test animals) prepared with normal saline water containing Tween80. Thirty minutes later phenobarbitone sodium ( 25 $\mathrm{mg} / \mathrm{kg} \mathrm{bw}$ ) was administered intraperitonially to all the groups to induce sleep. The onset of sleep and total sleeping time were recorded for both control and treated groups.

Antidiarrhoeal activity: Antidiarrheal activity was evaluated by using castor oil induced diarrhoea in mice (Agbor et al., 2014). The animals were divided into negative control, positive control and two test groups containing three mice in each group. Control group received vehicle (1\% Tween 80 in normal saline) at dose $10 \mathrm{ml} / \mathrm{kg}$ bw orally. The positive control group received loperamide at the dose of $50 \mathrm{mg} / \mathrm{kg}$ bw orally. The test group mice received methanolic extract of $B$. glomerulifera at 200 and $400 \mathrm{mg} / \mathrm{kg}$ bw. Each mouse was placed in an individual cage and the floor lining was changed at every hour. Diarrhea was induced by oral administration of castor oil to each mouse after the above treatment. During an observation period of 5 hours the number of diarrheic faeces excreted by the animals was recorded.

Statistical analysis: For all bioassays, the values are values are reported as mean \pm standard error of mean (SEM) and standard t-test was used to 
determine the significance between the control group and experimental groups, the $\mathrm{p}$ values $(\mathrm{p}<0.05)$ considered to be statistically significant.

\section{Results and Discussion}

Table 1 shows of the time of onset of sleep and total sleeping time of the test group mice of phenobarbitone induced sleeping time test (antidepressant activity). Total sleeping time of the test animals were 29.70 and $106.3 \mathrm{~min}$ for the doses of 200 and $400 \mathrm{mg} / \mathrm{kg} \mathrm{bw}$, respectively. For the standard chlorpromazine, total sleeping time for the treated mice was $172.0 \mathrm{~min}$.

In the castor oil-induced diarrheal experiment, the methanol extract of $B$. glomerulifera produced marked antidiarrheal effect in mice, as shown in table 2. Inhibition of diarrhea for the animals of test group found to be 62.50 at $200 \mathrm{mg} / \mathrm{kg}$ bw and 54.56 at 400 $\mathrm{mg} / \mathrm{kg}$ bw. Standard loperamide also exhibited potent inhibition $(65.55 \%)$ of diarrheal faeces but at a much lower dose than the crude extract.

Table 1. Antidepressant activity of methanolic extract of leaf of $\boldsymbol{B}$. glomerulifera.

\begin{tabular}{|c|c|c|c|}
\hline Groups & $\begin{array}{c}\text { Dose } \\
(\mathrm{ml} / \mathrm{kg} \text { or } \mathrm{mg} / \mathrm{kg} \mathrm{bw})\end{array}$ & $\begin{array}{l}\text { Time of onset of sleep } \\
\text { (min) }\end{array}$ & $\begin{array}{c}\text { Total sleeping time } \\
(\mathrm{min})\end{array}$ \\
\hline Control (normal saline) & 10 & $17.33 \pm 0.512$ & 86.0 \\
\hline Chlorpromazine (standard drug) & 25 & $16.33 \pm 0.324$ & $172.0^{*}$ \\
\hline \multirow[t]{2}{*}{ Crude extract of $B$. glomerulifera } & 200 & $58.33 \pm 0.441$ & 29.7 \\
\hline & 400 & $55.33 \pm 0.323$ & $106.3^{*}$ \\
\hline
\end{tabular}

All values are expressed as mean $\pm \mathrm{SEM} ; \mathrm{n}=3,{ }^{*} \mathrm{p}<0.05$ indicates significant compared to control.

Table 2. Antidiarrheal activity (in terms of \% inhibition) of $B$. glomerulifera extract.

\begin{tabular}{lccc}
\hline Groups & $\begin{array}{c}\text { Dose } \\
(\mathrm{ml} / \mathrm{kg} \text { or } \mathrm{mg} / \mathrm{kg} \mathrm{bw})\end{array}$ & $\begin{array}{c}\text { Number of diarrheal faeces } \\
(\text { Mean }) \pm \text { SEM }\end{array}$ & $\begin{array}{c}\text { Inhibition of diarrhea } \\
(\%)\end{array}$ \\
\hline Control (normal saline) & 10 & $6.0 \pm 0.52$ & -- \\
Loperamide (standard drug) & 50 & $1.97 \pm 0.77$ & $65.55^{*}$ \\
Crude extract of $B$. & 200 & $2.25 \pm 0.43$ & 62.50 \\
glomerulifera & 400 & $2.75 \pm 0.56$ & $54.56^{*}$ \\
\hline
\end{tabular}

All values are expressed as mean $\pm \mathrm{SEM} ; \mathrm{n}=3$, $* \mathrm{p}<0.05$ indicates significant compared to control

Phenobarbitone-induced sleeping test was carried out for the evaluation of CNS antidepressant effect. After administration of the crude extract at $400 \mathrm{mg} / \mathrm{kg}$ bw, total sleeping time of the test animals was increased in comparison to control which was found to be statistically significant. By potentiating the phenobarbitone-induced sleep, the extracts seem to possess sleep inducing properties (Fastier et al., 1957).

On the other hand, the methanolic crude extract of B. glomerulifera demonstrated potent antidiarrheal activity at both doses of 200 and $400 \mathrm{mg} / \mathrm{kg}$ bw of test animals in castor oil-induced diarrhea. However, anti-diarrheal effect observed at $400 \mathrm{mg} / \mathrm{kg}$ bw was found to be statistically significant. The inhibition of diarrhea by the plant extract may be due to inhibition of excessive peristaltic movement by the plant extract which was induced by oral administration of castor oil (Shoba et al., 2001).

\section{Conclusion}

On the basis of our results, it may be concluded that methanolic extract of B. glomerulifera exhibited dose dependant antidepressant as well as antidiarrheal activities. However, further studies are 
necessary to examine the underlying mechanisms of these effects and to isolate the active compound(s) responsible for these pharmacological activities.

\section{References}

Agbor, G.A., Longo, F., Makong, E.A. and Tarkang, P.A. 2014. Evaluation of the antidiarrheal and antioxidant properties of Justicia hypocrateriformis. Pharm. Biol. 52, 1128-1133.

Bandaranayake, W. M. 2006. Quality control, screening, toxicity, and regulation of herbal drugs. In: Modern Phytomedicine. Turning Medicinal Plants into Drugs, eds: Ahmad, I., Aqil, F. and Owais M., editors. (Weinheim:Wiley-VCH GmbH \& Co. KGaA). pp. 2557.

Bodeker, C., Bodeker, G., Ong, C. K., Grundy, C. K., Burford, G. and Shein, K. 2005. WHO Global Atlas of Traditional, Complementary and Alternative Medicine, World Health Organization: Geneva, Switzerland.

Borris, J, 1996. natural products research perspectives from a major pharmaceutical company. Merck Research Laboratories. J. Ethnopharmcol. 51, 29-38

Faruk, M.A., Khan, M.F., Mian, M.Y., Rahman, M.S. and Rashid, M.A. 2015. Analgesic and anti-diarrheal activities of Aganosma dichotoma (Roth) K. Schum. in Swiss-Albino mice model. Bangladesh Pharm. J. 18, 15-19.

Fastier, F.N., Spenden, R.N. and Hendrieka, W. 1957. Prolongation of chloral hydrate sleeping time by 5HT and by certain other drugs. Br. J. Pharmacol. Chemother. 12, 251.

Inamdar, N., Edalat, S., Kotwal, V.B., and Pawar, S. 2008. Herbal drugs in milieu of modern drugs. Int. J. Green Pharm. 2, 2-8.

Jiarui, C. and Friis, I.C. 2003. Wilmot-Dear M. Boehmeria. Flora China 5, 164-174.
Kelly, K. 2009. What the mummies reveal. In: History of Medicine. Facts on File: New York, pp. 29-50.

Khan, M.F, Khan, Z.I., Uddin, M.R., Rahman, M.S. and Rashid, M.A. 2015 In vivo hypoglycemic and alloxan induced antidiabetic activity of Xeromphis uliginosa Retz. Afr. J. Pharm. Pharmacol. 9, 363-366.

Khan, M.F., Rabbi, S.N.I., Hossain, M.A. and Rashid, M.A. 2014. Membrane stabilizing and thrombolytic activities of Sida rhombifolia L. Bangladesh Pharm. J. 17, 43-45.

Lowery, C.A., Johnson, P.L. Hay-Schmidt, A., Mikkelsen, J. and Shekhar, A. 2005. Modulation of anxiety circuits by serotonergic systems. Stress. 8, 233-246.

Mukharjee, P.K., Saha, K., Balasubramanium, R., Pal, M. and Saha, B.P. 1996. Studies of psychopharmacological effects of Nelumbo nucifera Gaertn. Rhizome extract. J. Ethnopharmacol. 54, 6367.

Mukherjee, P.W. 2002. Quality Control of Herbal Drugs: An Approach to Evaluation of Botanicals. Business Horizons Publishers: New Delhi, India.

Petrovska, BB. 2012. Historical review of medicinal plants' usage. Pharma. Rev. 6, 1-5.

Rahman, M.A., Uddin, S.B. and Wilcock, C.C. 2007. Medicinal plants used by Chakma tribe in hill tracts districts of Bangladesh. Ind. J. Trad. Knowledge 6, 508-517.

Shoba, F.G. and Thomas, M. 2001. Study of antidiarrhoeal activity of four medicinal plants in castor-oil induced diarrhoea. J. Ethnopharmacol. 76,73-76.

Stojanoski, N. 1999. Development of health culture in Veles and its region from the past to the end of the $20^{\text {th }}$ century. Veles: Soc. Sci. Art. 13-34.

Turner, R.A. 1972. Screening Procedure in Pharmacology, Academic Press: New York. 1st ed., pp. 78. 